\title{
CURAHAN WAKTU KERJA SEBAGAI INDIKATOR KEBERHASILAN PENGELOLAAN HUTAN RAKYAT "WANAFARMA" DI KECAMATAN MAJENANG KABUPATEN CILACAP
}

\author{
Working Time Allocation as Succes Indicator of Wanafarma Private Forest Management \\ in Majenang Sub District, Cilacap District
}

\author{
Eva Fauziyah, Dian Diniyati dan/and Tri Sulistiyati Widyaningsih \\ Balai Penelitian Teknologi Agroforestry \\ Jl. Raya Ciamis-Banjar km 4 Ciamis 46201 \\ Telp. (0265) 771352, Faks. (0265) 775886
}

Naskah masuk : 25 Maret 2013; Naskah diterima : 24 Februari 2014

\begin{abstract}
The research aims to know working time allocation of farmer in private forest and influencing factors in Bener Village, Sepatnunggal Village, and Sedahayu Village, Majenang Sub-District, Cilacap District. The methode was a direct interview with 19 respondent for each village. Data collected were processed with SPSS and descriptively analyzed. The result showed that weekly working time allocation of farmers in wanafarma private forest in three study village, were 4.4 Man Day=26.4 hours for Bener Village, Sepatnunggal Village 3.9 Man Day=23.4 hour, and Sadahayu Village 2.7 Man Day=16.2 hours. Time allocation of farmaers for each village was influenced by different factors. Time allocation in Bener Village was influenced by level of income and age, Sepatnunggal Village by income from private forest, age, farmer experience, education and land areas, and Sedahayu Village by age, farmer experience, and land area.
\end{abstract}

Keywords: Farmer, working time allocation, wanafarma private forest

\begin{abstract}
ABSTRAK
Salah satu pola pengelolaan hutan rakyat adalah pola wanafarma. Pendapatan petani dari hutan rakyat pola wanafarma akan berbeda-beda tergantung pada tingkat pemeliharaan yang dilakukan dan curahan waktu kerja dari petani. Curahan waktu kerja tersebut dapat dipengaruhi oleh berbagai faktor baik internal maupun eksternal. Penelitian ini bertujuan untuk mengetahui curahan waktu kerja petani di dalam hutan rakyat wanafarma dan faktorfaktor yang mempengaruhinya. Penelitian ini dilakukan di Desa Bener, Desa Sepatnunggal, dan Desa Sadahayu Kecamatan Majenang Kabupaten Cilacap. Metode pengumpulan data dilakukan dengan wawancara terhadap petani hutan rakyat dengan jumlah responden 19 orang setiap desa. Data yang diperoleh diolah dengan menggunakan SPSS dan dianalisis secara deskriptif. Hasil penelitian menunjukkan curahan waktu kerja petani di hutan rakyat wanafarma setiap minggu di ketiga desa berturut-turut adalah Desa Bener $=4,4 \mathrm{HOK}(26,4 \mathrm{jam}$, Desa Sepatnunggal $=3,9 \operatorname{HOK}(23,4 \mathrm{jam})$, dan Desa Sadahayu $=2,7 \mathrm{HOK}(16,2 \mathrm{jam})$. Curahan waktu kerja petani di ketiga desa tersebut dipengaruhi oleh faktor yang berbeda-beda. Curahan waktu kerja petani di Desa Bener dipengaruhi oleh besarnya pendapatan dari hutan rakyat dan umur petani, Desa Sepatnunggal dipengaruhi oleh pendapatan dari hutan rakyat, umur, pengalaman tani, pendidikan, dan luas lahan, sedangkan curahan waktu kerja petani di Desa Sedahayu dipengaruhi oleh pendapatan dari hutan rakyat, umur, pengalaman usaha tani, dan luas lahan.
\end{abstract}

Kata kunci: Petani, curahan waktu kerja, hutan rakyat wanafarma 


\section{PENDAHULUAN}

\section{A. Latar Belakang}

Menurut Dirjen RRL (1997), hutan rakyat adalah hutan yang tumbuh di atas tanah yang dibebani hak milik maupun hak lainnya dengan ketentuan luas minimum 0,25 ha dan penutupan tajuk tanaman kayu-kayuan lebih dari 50\% dan atau pada tanaman tahun pertama sebanyak minimal 500 batang tanaman. Salah satu jenis kombinasi hutan rakyat adalah wanafarma. Hutan rakyat wanafarma adalah hutan rakyat yang di dalamnya merupakan kombinasi antara tanaman kayu dengan tanaman obat. Selain tanaman obat ada juga petani yang menanam tanaman lain seperti tanaman palawija dan tanaman lainnya seperti tanaman perkebunan.

Kabupaten Cilacap khususnya Kecamatan Majenang dikenal sebagai penghasil tanaman obat (empon-empon) yang cukup besar. Peluang pasar bagi tanaman obat di daerah ini memang terbuka lebar, mengingat bahwa Kabupaten Cilacap merupakan sentra produsen jamu yang tentunya membutuhkan bahan baku berupa tanaman obat dalam jumlah banyak. Bahan baku ini diperoleh tidak hanya dari petani yang mengembangkan empon-empon secara monokulur, melainkan juga dikumpulkan dari lahan petani yang dikelola dengan sistem agroforestri dengan tanaman kayu, yang dikenal dengan pola wanafarma (red: wana $=$ hutan, dan farma $=$ obat).

Penelitian Mile \& Siarudin (2005) menyatakan untuk beberapa kasus, hutan rakyat model wanafarma seperti hutan rakyat pola tanam campuran antara sengon dengan jahe yang diujicobakan di Kecamatan Majenang juga memberikan hasil yang positif, baik tanaman kayu maupun jahenya dapat tumbuh baik dengan pemeliharaan intensif dari petani. Pendapatan yang diperoleh petani yang menerapkan pola agroforestri termasuk pola wanafarma berbeda-beda tergantung pada tingkat pemeliharaan yang dilakukan oleh pemiliknya. Hasil penelitian Siregar et al. (2007) terhadap kombinasi tanaman sengon dan nanas di Kediri, Jawa Timur memperlihatkan bahwa hutan rakyat yang dikelola secara agroforestri lebih menguntungkan pemiliknya karena dengan model penanaman agroforestri maka petani memperoleh keuntungan yang lebih tinggi. Namun keputusan dalam mengelola lahan tersebut sangat dipengaruhi oleh beberapa faktor diantaranya adalah luasan lahan, harga kayu dan periode penanaman.
Salah satu faktor yang membedakan hasil hutan rakyat adalah curahan waktu kerja dari petani itu sendiri. Curahan waktu kerja petani di hutan rakyat merupakan intensitas perhatian masyarakat terhadap hutan rakyat dan akan menentukan keberhasilan pengelolaan hutan rakyat, terutama keberhasilan secara ekonomi yaitu terhadap peningkatan pendapatan. Harapannya selain adanya peningkatan pendapatan, curahan tenaga kerja petani di hutan rakyat juga dapat meningkatkan kondisi lingkungan. Dalam penelitian ini difokuskan pada kaitan peningkatan curahan tenaga kerja dengan keberhasilan dalam pengelolaan hutan rakyat secara sosial dan ekonomi. Curahan waktu kerja tersebut dapat dipengaruhi oleh berbagai faktor baik internal maupun eksternal. Oleh karena itu penelitian ini dilakukan dengan tujuan untuk mengetahui intensitas masyarakat mencurahkan waktu kerjanya di hutan rakyat wanafarma dan faktor-faktor yang mempengaruhinya. Hasil penelitian ini diharapkan dapat memberikan gambaran bagi peningkatan pendapatan petani dari hutan rakyat khususnya yang dikelola dengan pola wanafarma.

\section{B. Tujuan}

Penelitian bertujuan untuk mengetahui tingkat curahan waktu kerja petani di hutan rakyat wanafarma dan faktor-faktor yang mempengaruhinya.

\section{METODOLOGI}

\section{A. Lokasi dan Waktu}

Penelitian dilakukan di Desa Bener, Desa Sepatnunggal, dan Desa Sadahayu Kecamatan Majenang Kabupaten Cilacap. Kegiatan ini dilaksanakan pada bulan Mei sampai dengan bulan Agustus 2006. Peta lokasi kegiatan penelitian dapat dilihat pada Gambar 1.

\section{B. Metode Pengumpulan Data}

Data primer yang dikumpulkan dari responden terdiri dari jati diri responden seperti jenis kelamin, umur, pendidikan, pekerjaan utama, pekerjaan sampingan, pendapatan dari pekerjaan utama maupun sampingan, luas lahan hutan rakyat, serta curahan waktu kerja di hutan rakyat. Data ini diperoleh melalui wawancara dengan menggunakan kuesioner yang telah dipersiapkan sebelumnya. Responden yang dipilih seba- 


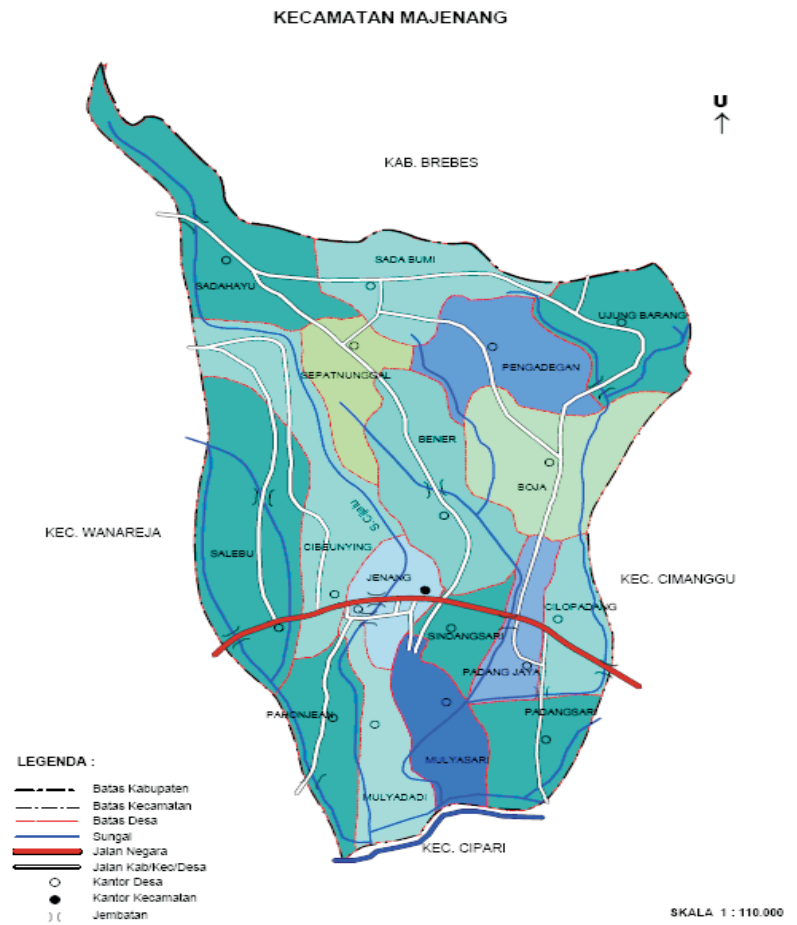

Gambar (Figure) 1. Peta lokasi penelitian (Research location map) Sumber (Source): BPS Kabupaten Cilacap (2006)

nyak 19 orang setiap desa, responden ini dipilih dengan kriteria petani yang mengelola hutan rakyat wanafarma (menanam tanaman kayu dan tanaman obat di lahannya). Data sekunder dikumpulkan dari data yang tersedia di desa, kecamatan, dan lain-lain yang berhubungan dengan penelitian ini.

\section{Analisis Data}

Data yang diperoleh dikelompokkan dalam bentuk tabulasi dan dianalisis dengan regresi linier berganda menggunakan software statisik SPSS 11.5 for windows. Dengan asumsi bahwa tingkat (curahan waktu kerja) dalam pengelolaan hutan rakyat merupakan fungsi dari faktorfaktor sosial ekonomi respoden maka persamaan tersebut adalah sebagai berikut:

$$
\begin{aligned}
Y i= & b_{0}+b_{1} i X_{1} i+b_{2} i x_{2} i+b_{3} i X_{3} i+b_{4} i X_{4} i+b_{5} i X_{5} i \\
& +b_{6} i X_{6} i+E i
\end{aligned}
$$

Dimana: $\mathrm{Yi}=$ tingkat curahan waktu kerja, $\mathrm{X}_{1} \mathrm{i}=$ pendapatan responden dari hutan rakyat, $\mathrm{X}_{2} \mathrm{i}=$ pendapatan dari non hutan rakyat, $\mathrm{X}_{3} \mathrm{i}$ $=$ umur responden, $\mathrm{X}_{4} \mathrm{i}=$ pengalaman usaha tani, $\mathrm{X}_{5} \mathrm{i}=$ pendidikan $\operatorname{dan} \mathrm{X}_{6} \mathrm{i}=$ luas lahan respoden; $\mathrm{b}_{0}=$ konstanta (interceps), $\mathrm{b}_{1}, \mathrm{~b}_{2}, \mathrm{~b}_{3}, \mathrm{~b} 4, \mathrm{~b}_{5}$ dan $\mathrm{b}_{6}=$ koefisien-koefisien regresi dan $\mathrm{Ei}=$ faktor koreksi.
Dari beberapa persamaan yang diperoleh, dipilih model persamaan regresi yang terbaik dengan kriteria $\mathrm{R}^{2}$ terbesar dan Standar Error of Estimate terkecil serta tidak terdapat multikolinieritas, kemudian dianalisis secara deskriptif.

\section{HASIL DAN PEMBAHASAN}

\section{A. Karakteristik Responden}

Ketiga desa studi merupakan wilayah yang diprioritaskan untuk pengembangan hutan rakyat di Kabupaten Cilacap. Karakteristik rata-rata responden pada ketiga desa studi disajikan pada Tabel 1.

Responden umumnya termasuk kategori usia produktif (15-54 tahun) di mana umur rata-rata responden untuk Desa Bener, Sepatnunggal dan Sadahayu berturut-turut 52 tahun, 50 tahun, dan 47 tahun. Dengan kondisi tersebut diharapkan pengelolaan hutan rakyat dapat berjalan lebih optimal karena dilakukan oleh petani yang dilihat dari tingkatan usia masih mempunyai banyak tenaga untuk mengelola dan mengembangkan hutan rakyat. Hasil penelitian Sobari et al. (1996) memperlihatkan tenaga kerja pria muda lebih banyak mencurahkan tenaganya untuk mencari 
Tabel(Table) 1. Karakteristik responden di Desa Bener, Sepatnunggal, dan Sedahayu (rata-rata) (Characteristic of respondent at Bener, Sepatnunggal, dan Sedahayu Village (average))

\begin{tabular}{clccc}
\hline \multirow{2}{*}{ No. } & \multicolumn{1}{c}{$\begin{array}{c}\text { Karakteristik } \\
\text { (Characteristic) }\end{array}$} & Bener & Desa (Village) \\
\cline { 3 - 5 } & \multicolumn{1}{c}{ Sepatnunggal } & Sedahayu \\
\hline 1. & Umur (Th) & 51,84 & 49,63 & 47,05 \\
2. & Pendidikan (Th) & 4,74 & 6,84 & 5,84 \\
3. & Luas lahan (Ha) & 0,86 & 1,12 & 1,52 \\
4. & Pengalaman usaha tani (Th) & 34,89 & 31,89 & 32,32 \\
5. & Pendapatan HR (Rp / Th) & 2.973 .578 & 1.426 .701 & 1.639 .342 \\
6. & Pendapatan non HR (Rp / Th) & 6.606 .215 & 6.790 .429 & 5.515 .600 \\
\hline
\end{tabular}

Sumber (source): Data primer(Primary data) (2006)

Keterangan (Remarks): Non HR adalah kegiatan respoden selain hutan rakyat meliputi : sawah, jasa, dagang, dan ternak (Non-HR respondents are activities other than public forests include: ricefield, services, trade, and livestock)

nafkah. Fatati (2001) dalam Sani et al. (2010) juga menyebutkan bahwa semakin muda umur seseorang maka semakin mudah menerima perubahan dari luar karena petani peternak selalu ingin mencoba sesuatu yang baru sebagai upaya meningkatkan pengetahuan dan keterampilan dalam diversifikasi usahanya. Sebaliknya menurut Suratiyah (2006) dalam Sani et al. (2010) bahwa semakin bertambah usia seseorang maka semakin menurun pula produktivitas kerjanya. Thangata \& Alavalapati (2003) dalam Kristkova \& Kalabisova (2010) juga menyatakan bahwa petani yang berusia lebih muda lebih memungkinkan dalam mengadopsi teknologi agroforestri.

Dari segi pendidikan, sebagian besar responden berpendidikan rendah karena hanya menempuh pendidikan sampai dengan tingkat SD (baik tamat maupun tidak). Oleh karena itu meskipun pengalaman berusaha tani responden sebagian besar sudah cukup lama (rata-rata sudah berusaha tani lebih dari 30 tahun) masih harus didukung oleh penyuluhan, pelatihan, pendampingan sehingga petani mendapatkan masukan/ tambahan informasi/pengetahuan terkait dengan pengelolaan hutan rakyatnya misalnya penggunaan tindakan silvikultur (pemeliharaan) untuk mendapatkan hasil yang optimal. Fatati (2001) dalam Sani et al. (2010) menyatakan tingkat pendidikan memiliki peran penting dalam memahami penggunaan teknologi untuk dapat meningkatkan produktivitas usaha pertanian karena semakin tinggi pendidikan maka akan lebih mudah memahami dan menerapkan teknologi baru serta mempunyai wawasan berpikir yang lebih luas. Dengan tingkat pendidikan yang masih rendah maka pekerjaan yang tersedia adalah sebagai petani, buruh tani, ataupun sebagai buruh sadap getah pinus di Perum Perhutani.
Pengelolaan hutan rakyat oleh petani dilakukan di lahan milik secara swadaya dengan kepemilikan lahan milik relatif lebih luas dibandingkan lahan garapan (lahan dari desa ataupun Perum Perhutani yang berdekatan dengan wilayah tersebut). Luas lahan yang dimiliki petani yang sebagian besar digunakan untuk pengusahaan hutan rakyat berkisar antara 0,86-1,52 ha, sedangkan luas lahan garapan rata-rata hanya 0,09 ha di Desa Bener, 0,00 ha di Desa Sepat-nunggal, dan 0,12 ha di Desa Sadahayu. Secara umum rasio kepemilikan lahan usahatani bagi sebagian besar petani di Jawa sudah sangat rendah (Andayani, 2005).

\section{B. Kontribusi Hutan Rakyat Wanafarma terhadap Pendapatan Respoden}

Kondisi hutan rakyat pada umumnya ditanam dengan pola agroforestri antara tanaman tahunan seperti kayu-kayuan, buah-buahan dengan tanaman pertanian, tanaman perkebunan, dan tanaman obat seperti padi (Oryza sativa), jagung (Zea mays), ketela pohon (Manihot esculenta), cengkeh (Eugenia aromatica), kapolaga (Amomum cardamomum), jahe (Zingiber officinale), kunyit (Curcuma domestica), lengkuas (Alpinia galanga), kencur (Keempferia sp.), dan sebagainya. Dengan adanya pengaturan jenis tanaman tersebut maka akan diperoleh pendapatan secara periodik sesuai dengan periode waktu panen. Menurut Awang et al. (2002), hutan rakyat dengan segala komoditasnya secara siginifikan telah membantu memenuhi ragam kebutuhan petani pemiliknya, baik untuk tambahan pendapatan, bahan obat-obatan, sumber pangan, sumber pakan ternak, tabungan pendidikan anak dan untuk sumber bahan bangunan perumahan dan mebeler. 
Tabel 1 menunjukkan bahwa pendapatan ratarata responden per tahun dari hutan rakyat adalah Desa Bener sebesar Rp 2.973.500,-; Desa Sedahayu sebesar Rp 1.426.700,-; dan Desa Sepatnunggal sebesar Rp 1.639.300,- dengan rata-rata luas lahan hutan rakyat untuk Desa Bener 0,86 ha, Desa Sedahayu 1,52 ha, dan Desa Sepatnunggal 1,12 ha; sedangkan rata-rata curahan waktu kerja responden terlihat pada Tabel 2, untuk Desa Bener 222,21 HOK, Desa Sepatnunggal 131,34 HOK, dan Desa Sedahayu 139,08 HOK. Dari data tersebut dapat dilihat bahwa ada kecenderungan di mana rata-rata luas lahan hutan rakyat yang tinggi tidak selalu menghasilkan pendapatan yang paling besar, namun curahan waktu kerja yang besar akan menghasilkan pendapatan yang paling tinggi.

Berdasarkan perhitungan pada Tabel 2 juga terlihat bahwa, "semakin luas lahan hutan rakyat semakin rendah pendapatannya per hektar". Hal tersebut karena petani yang memiliki lahan luas cenderung tidak mengelolanya secara intensif, yang terlihat dari curahan waktu yang diberikan terhadap hutan rakyatnya dan jenis penyusun hutan rakyat yang dibudidayakannya. Petani dengan lahan hutan rakyat yang luas kebanyakan hanya menanami lahannya dengan tanaman kayu saja sedangkan petani yang memiliki lahan sempit berusaha memanfaatkan lahannya secara optimal.

Jenis tanaman yang diusahakan lebih beragam mulai dari tanaman kayu, tanaman buah, palawija dan tanaman obat. Terlebih lagi beberapa petani yang memiliki lahan hutan rakyat luas, juga memiliki lahan sawah yang memerlukan curahan waktu yang cukup banyak. Hasil penelitian Zakaria (2012) di Nusa Tenggara Barat memperlihatkan semakin luas lahan sawah yang diusahakan maka semakin besar penyerapan tenaga kerja keluarga, sementara untuk usahatani la-

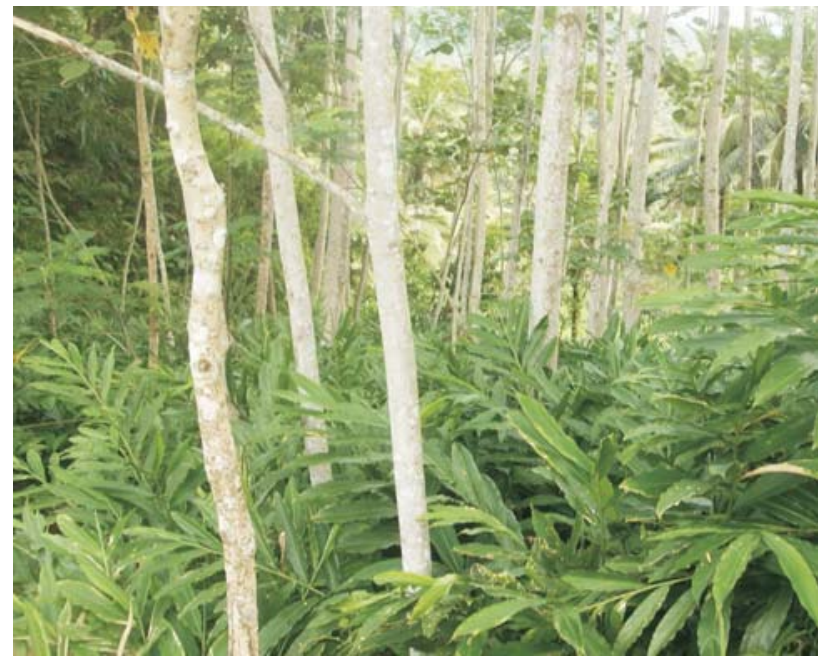

Gambar (Figure) 2. Hutan rakyat "wanafarma" antara sengon dengan kapulaga (Wanafarma private forest between sengon and kapulaga)

Tabel(Table) 2. Pendapatan petani berdasarkan luasan hutan rakyat dan curahan waktu kerja (Farmer income based on private forest area and working time allocation)

\begin{tabular}{lcccc}
\hline $\begin{array}{c}\text { Desa } \\
\text { Village) }\end{array}$ & $\begin{array}{c}\text { Rata-rata luas lahan } \\
\text { (ha) }\end{array}$ & $\begin{array}{c}\text { Rata-rata curahan waktu } \\
\text { kerja (HOK/Tahun) } \\
\text { (Average ofworking } \\
\text { time allocation(Man } \\
\text { Day/Year) }\end{array}$ & $\begin{array}{c}\text { Pendapatan per } \\
\text { ha per tahun } \\
\text { (Rp) } \\
\text { (Income per } \\
\text { ha) }\end{array}$ & $\begin{array}{c}\text { Pendapatan per } \\
\text { HOK per tahun } \\
\text { (Rp) }\end{array}$ \\
(Income per MD) \\
\hline Bener & 0,86 & 222,21 & 3.457 .651 & 13.381 \\
Sepatnunggal & 1,52 & 131,4 & 938.619 & 10.258 \\
Sedahayu & 1,12 & 139,105 & 1.463 .698 & 12.481 \\
\hline
\end{tabular}

Sumber (source): data primer ( primary data) (2006)

Keterangan (Remarks): 1 HOK (Hari Orang Kerja)(Man Day $(M D))=6$ jam (hours) 
Tabel(Table) 3. Kontribusi hutan rakyat wanafarma terhadap pendapatan total respoden (Contributions of wanafarma private forest toward total income of respondent)

\begin{tabular}{cccccc}
\hline No. & \multicolumn{1}{c}{$\begin{array}{c}\text { Desa } \\
\text { (Village) }\end{array}$} & $\begin{array}{c}\text { Pendapatan HR } \\
\text { Wanafarma } \\
\text { (Income from } \\
\text { Wanafarma Private } \\
\text { Forest) }\end{array}$ & $\begin{array}{c}\text { Pendapatan } \\
\text { Total } \\
\text { (Total Income ) }\end{array}$ & $\begin{array}{c}\text { Kontribusi HR } \\
\text { Wanafarma } \\
\text { (Wanafarma } \\
\text { Private Forest } \\
\text { Contributions) }\end{array}$ & $\begin{array}{c}\text { Kontribusi Non } \\
\text { HR (Non Private } \\
\text { Forest } \\
\text { Contributions) }\end{array}$ \\
\hline 1. & Bener & 37.778 .602 & 182.016 .100 & $20,76 \%$ & $79,24 \%$ \\
2. & Sepatnunggal & 19.981 .606 & 156.125 .500 & $12,80 \%$ & $87,20 \%$ \\
3. & Sadahayu & 21.677 .751 & 135.943 .904 & $15,95 \%$ & $84,05 \%$ \\
\hline
\end{tabular}

Sumber (Source): Data primer (Primary data) (2006)

dang/tegalan pada umumnya masih rendah. Hasil penelitian ini menyebutkan untuk pengusahaan tegalan dengan komoditas kelapa, mangga dan sawah seluas 0,53 hektar di Desa Tarusa NTB, diperlukan tenaga kerja sebanyak 79,3 HOK per tahun dimana sekitar 52\% atau 40,3 HOK merupakan tenaga kerja keluarga. Di Desa Kolaso dengan skala luas 0,85 hektar diperlukan tenaga kerja sebanyak 108,8 HOK dan sekitar $45 \%$ atau 49,2 HOK dipenuhi oleh tenaga kerja keluarga.

Selain itu petani lahan sempit sebagian besar mengandalkan sumber pendapatannya dari lahan tersebut, sehingga tidak jarang dengan lahan sempit yang dimilikinya petani berusaha memperoleh pendapatan yang maksimal. Andayani (2005) menilai hanya dengan strategi tersebut diharapkan kelak lahan usaha yang dimilikinya itu mampu menghasilkan output yang bernilai ekonomi tinggi. Upaya yang dilakukan adalah dengan mengusahakan beragam jenis tanaman dan tidak hanya untuk dikonsumsi langsung tetapi juga untuk dijual agar dapat memenuhi kebutuhan lainnya. Oleh karena itu merupakan hal yang wajar apabila pendapatan petani di Desa Bener yang paling sempit rata-rata kepemilikan lahannya justru lebih besar pendapatan dibandingkan kedua desa lainnya yang rata-rata kepemilikan lahannya lebih luas.

Berdasarkan curahan waktu kerja seperti terlihat pada Tabel 2 pendapatan petani dari hutan rakyat per HOK di Desa Bener lebih besar dari Desa Sepatnunggal dan Desa Sedayu. Hal itu disebabkan karena aktivitas petani di Desa Bener jauh lebih produktif dan sumber pendapatan yang bisa diperoleh dari hutan rakyatnya lebih banyak, sehingga dengan rata-rata per hari petani bekerja selama 6 jam di hutan rakyat penghasilan yang diperolehnya lebih besar, sedangkan di desa lain petaninya cenderung kurang produktif. Petani di Desa Sedahayu mengaku pergi ke kebun (hutan rakyat) hanya untuk melihat-lihat atau membersihkan rumput saja, tidak menghasilkan sesuatu yang dapat dikonsumsi atau dijual (sebagai sumber pendapatannya), bahkan petani di kedua desa ini mengaku meskipun hutan rakyatnya dikelola dengan wanafarma, namun tidak dikembangkan secara serius baik tanaman kayu maupun tanaman obatnya.

Hutan rakyat wanafarma di ketiga desa memberikan kontribusi yang masih rendah terhadap pendapatan total respoden. Terlihat pada Tabel 3 hutan rakyat di Desa Bener hanya memberikan kontribusi sebesar 20,76\% terhadap pendapatan total responden selebihnya dari sektor lain; sedangkan hutan rakyat di Desa Sepatnunggal dan Sedahayu masing-masing memberikan kontribusi sebesar $12,80 \%$ dan $15,95 \%$ dari total pendapatan responden. Meskipun nilai kontribusinya rendah, pendapatan dari hutan rakyat cukup berpengaruh terhadap tercurahnya waktu kerja petani petani di hutan rakyat.

\section{Curahan Waktu Kerja Petani terhadap Pengelolaan Hutan Rakyat}

Curahan waktu kerja petani dalam pengelolaan hutan rakyat didefinisikan sebagai jumlah jam kerja riil (HOK) yang dicurahkan oleh petani (termasuk anggota keluarga) dalam pengelolaan hutan rakyat dalam satu tahun. Curahan waktu kerja merupakan faktor yang menentukan produktivitas kerja yang pada akhirnya akan menentukan tingkat pendapatannya. Curahan waktu kerja responden di setiap desa disajikan pada Tabel 4.

Intensitas kegiatan masyarakat dalam pengelolaan hutan rakyat cukup tinggi. Hal ini dapat dilihat dari curahan jam kerja responden pada hutan rakyat yang lebih banyak dibanding-kan curahan jam kerja pada non hutan rakyat/ sektor lain. Kegiatan masyarakat di hutan rakyat mulai dari 
membersihkan lahan, membuat ajir, menanam, merawat (menyiram, memupuk, membasmi hama, menyiangi tanaman), sampai proses pemanenan. Curahan jam kerja dan kegiatan masyarakat baik di hutan rakyat maupun sektor lain merupakan salah satu indikator produktivitas kerja masyarakat.

Dari Tabel 4 dapat dilihat bahwa curahan waktu kerja di hutan rakyat dari yang paling besar berturut-turut per minggu adalah Desa Bener (4,4 $\mathrm{HOK}=26,4 \mathrm{jam}$, Desa Sepatnunggal $(3,9 \mathrm{HOK}=$ 23,4 jam), dan Desa Sadahayu (2,7 HOK = 16,2 jam). Rata-rata curahan waktu kerja responden di hutan rakyat pada ketiga desa studi masih di bawah curahan jam kerja normal per minggu yakni 44 jam (BPS Kabapaten Cilacap, 2006). Meskipun curahan waktu kerja di ketiga desa tersebut masih di bawah standar jam kerja normal, namun tetap menunjukkan intensitas yang tinggi dalam mengelola hutan rakyatnya. Hal ini memperlihatkan adanya kepedulian untuk menjaga lingkungan melalui penanaman tanaman kayu-kayuan yang berfungsi sebagai penahan banjir dan longsor sekaligus dapat memberikan pendapatan bagi petani.

Dengan tidak membedakan jenis pekerjaannya, maka curahan waktu kerja petani diharapkan dapat memberikan kontribusi terhadap pendapatan petani itu sendiri. Karyawan et al. (1996) mengasumsikan bahwa peran serta atau penyerapan tenaga kerja tergantung pada tingkat pendapatan, pengalaman kerja, umur, pendidikan, dan sumber pendapatan lain. Dari asumsi tersebut kemudian dilakukan analisis statistik dan hasilnya menunjukkan bahwa tidak semua faktor yang ada tersebut memberikan pengaruh yang signifikan (memiliki hubungan yang erat) dengan curahan waktu petani di hutan rakyat dan faktorfaktor yang mempengaruhi curahan waktu kerja terhadap pengelolaan hutan rakyat di setiap desa studi berbeda-beda. Persamaan regresi di Desa Bener, Desa Sepatnunggal, dan Desa Sedahayu disajikan pada Tabel 5 .

Dari hasil analisis yang pada awalnya menggunakan enam faktor penduga yang dapat mempengaruhi curahan waktu kerja petani di hutan

Tabel(Table) 4. Rata-rata curahan waktu kerja responden (Average working time allocation of respondents)

\begin{tabular}{|c|c|c|c|c|c|}
\hline \multirow[b]{2}{*}{ No. } & \multirow[b]{2}{*}{$\begin{array}{l}\text { Desa } \\
\text { Village }\end{array}$} & \multicolumn{2}{|c|}{$\begin{array}{c}\text { Curahan waktu kerja Tahunan (HOK) } \\
\text { Annual Time allocation }(M D)\end{array}$} & \multicolumn{2}{|c|}{$\begin{array}{c}\text { Curahan waktu kerja Mingguan (HOK) } \\
\text { Weekly Time allocation (MD) }\end{array}$} \\
\hline & & $\begin{array}{l}\text { Hutan Rakyat } \\
\text { Private Forest }\end{array}$ & $\begin{array}{l}\text { Non Hutan } \\
\text { Rakyat } \\
\text { Non Private } \\
\text { Forest }\end{array}$ & $\begin{array}{l}\text { Hutan Rakyat } \\
\text { Private Forest }\end{array}$ & $\begin{array}{l}\text { Non Hutan Rakyat } \\
\text { Non Private Forest }\end{array}$ \\
\hline 1. & Bener & 222,21 & 82,68 & 4,4 (26,4 jam) & $1,6(9,6$ jam $)$ \\
\hline 2. & Sepatnunggal & 131,34 & 123,09 & $3,9(23,4 \mathrm{jam})$ & $2,4(14,4 \mathrm{jam})$ \\
\hline 3. & Sadahayu & 139,05 & 87,23 & $2,7(16,2 \mathrm{jam})$ & $1,6(9,6$ jam $)$ \\
\hline
\end{tabular}

Sumber (Source): data primer ( primary data) (2006)

Keterangan (Remark): Non HR adalah kegiatan respoden selain hutan rakyat meliputi : sawah, jasa, dagang, dan ternak

Tabel(Table) 5. Persamaan regresi di Desa Bener, Desa Sepatnunggal, dan Desa Sedahayu ( Equation regression in Bener Village, Sepatnunggal Village, dan Sedahayu Village)

\begin{tabular}{lll}
\hline \multicolumn{1}{c}{$\begin{array}{c}\text { Desa } \\
\text { Village }\end{array}$} & \multicolumn{1}{c}{$\begin{array}{c}\text { Persamaan Regresi } \\
\text { Regression }\end{array}$} & \multicolumn{1}{c}{$\begin{array}{c}\text { Keterangan } \\
\text { Remarks }\end{array}$} \\
\hline Bener & $\mathrm{Y}=24,514+1,622 \mathrm{X}_{1}+2,883 \mathrm{X}_{3}$ & $\mathrm{R} 2=35,9 \%$, \\
& & Std. Error of estimate $=$ \\
& & 108,599 \\
\hline Sepatnunggal & $\mathrm{Y}=-548.337+3,31 \mathrm{X}_{1}+31,48 \mathrm{X}_{3}-23,399 \mathrm{X}_{4}-20,898 \mathrm{X}_{5}-$ & $\mathrm{R} 2=38,3 \%$, \\
& $36,209 \mathrm{X}_{6}$ & Std. Error of estimate $=$ \\
& & 122,627 \\
\hline Sedahayu & $\mathrm{Y}=-17,643-3,01 \mathrm{X}_{1}+7,32 \mathrm{X}_{3}-5,295 \mathrm{X}_{4}+21,559 \mathrm{X}_{6}$ & $\mathrm{R} 2=45,5 \%$, \\
& & Std. Error of estimate $=$ \\
& & 108,548 \\
\hline
\end{tabular}

Sumber (source): data dianalisis (analysed data) (2006)

Keterangan (Remarks): $\mathrm{X}_{1}=$ pendapatan (income) $\mathrm{HR}, \mathrm{X}_{2}=$ pendapatan (income) non $\mathrm{HR}, \mathrm{X}_{3}=\operatorname{umur}\left(\right.$ age), $\mathrm{X}_{4}=$ pengalaman usaha tani(farming experience), $\mathrm{X}_{5}=$ pendidikan(education), $\mathrm{X}_{6}=$ luas lahan(land area) 
rakyat, maka dipilih model terbaik untuk masingmasing desa dengan kriteria nilai $\mathrm{R}^{2}$ terbesar, Standar Error of Estimate terkecil, dan tidak terdapat multikolinieritas.

Dari Tabel 4 diketahui bahwa untuk Desa Bener curahan waktu kerja pada hutan rakyat wanafarma dipengaruhi oleh besarnya pendapat an dari hutan rakyat $\left(\mathrm{X}_{1}\right)$ dan umur petani $\left(\mathrm{X}_{3}\right)$. Hasil pendugaan variabel independent akan dapat menjelaskan perilaku penyerapan tenaga kerja sebesar 35,9\%. Persamaan di atas menunjukkan bahwa jika tidak ada pendapatan dari hutan rakyat dan umur maka penyerapan tenaga kerja adalah sebesar 24,514 HOK per tahun.

Faktor pendapatan dari hutan rakyat dan umur ini memberikan nilai pengaruh yang positif artinya apabila pendapatan hutan rakyat meningkat Rp.1,- akan meningkatkan curahan waktu kerja sebesar 1,622 HOK per tahun karena pendapatan yang besar akan menarik minat petani untuk mengoptimalkan pengelolaan hutan rakyatnya. Dari hasil analisis diketahui bahwa korelasi yang kuat (nilai korelasi $>0,5$ ) terjadi antara curahan waktu kerja dengan pendapatan hutan rakyat, dimana sebesar 0,6 (60\%), perilaku curahan waktu kerja dapat dijelaskan oleh pendapatan dari hutan rakyat yang diterima petani, sedangkan sisanya dijelaskan oleh faktor lainnya.

Peningkatan faktor umur petani 1 tahun juga akan dapat meningkatkan curahan tenaganya sebesar 2,883 HOK per tahun pada hutan rakyatnya dengan nilai korelasinya sebesar 0,46 . Hal ini menunjukkan bahwa seperti pada umumnya hutan rakyat lebih banyak diminati dan dikelola oleh petani yang berusia lanjut.

Perilaku curahan waktu kerja di Desa Sepat nunggal dijelaskan oleh beberapa faktor dengan $\mathrm{R}^{2}$ sebesar 38,3\%. Pada model regresi terpilih, di desa ini faktor yang berpengaruh besar meliputi pendapatan hutan rakyat $\left(\mathrm{X}_{1}\right)$, Umur $\left(\mathrm{X}_{3}\right)$, pengalaman $\left(\mathrm{X}_{4}\right)$, pendidikan $\left(\mathrm{X}_{5}\right)$, dan luas lahan $\left(\mathrm{X}_{6}\right)$. Jika tidak ada faktor-faktor tersebut Curahan waktu kerja petani terhadap hutan rakyat bernilai negatif sebesar $-548,337$ HOK per tahun, yang artinya bahwa tidak ada yang tercurah bahkan menurun sebesar 548,337HOK pertahun. Apabila ada peningkatan faktor pendapatan dari hutan rakyat sebesar Rp 1,- maka curahan waktu kerja akan mengalami peningkatan sebesar 3,31 HOK per tahun. Semakin bertambah 1 tahun umur petani akan meningkat curahan waktunya sebesar 31,48 HOK per tahun, tetapi berbanding terbalik dengan usia petani, pengalaman petani sebanyak 1 tahun akan menurunkan curahan waktunya di hutan rakyat sebanyak 23,399 HOK per tahun. Kadangkala petani yang memiliki pengalaman lebih banyak melakukan kegiatan lain baik dalam bidang pertanian atau bidang lainnya dibandingkan di hutan rakyat.

Demikian pula dengan pendidikan dan luas lahan yang dimiliki. Semakin tinggi pendidikan petani 1 tahun akan menurunkan curahan waktunya terhadap hutan rakyat sebesar 20,898 HOK per tahun. Hal ini disebabkan semakin tinggi pendidikan seseorang, maka pada umumya orang semakin enggan mengelola hutan rakyat dan lebih tertarik mencari pekerjaan lain ke kota. Dan hal inilah yang menyebabkan hutan rakyat tidak dapat berkembang dengan baik karena lebih banyak dikelola oleh petani usia lanjut dan pendidikan yang relatif rendah. Hasil penelitian Diniyati et al. (2005) di Garut dan Majalengka diketahui bahwa tingkat pendidikan berpengaruh negatif terhadap partisipasi petani di hutan rakyat, yang artinya partisipasi petani di hutan rakyat semakin menurun dengan meningkatnya pendidikan seseorang. Yang menjadi alasan mengapa terjadi demikian adalah bahwa seseorang yang pendidikannya tinggi tidak memilih menjadi petani hutan rakyat murni namun lebih memilih bekerja di sektor lain dan menjadikan hutan rakyatnya sebagai sampingan, sehingga waktu yang dicurahkan pada hutan rakyatnya relatif rendah. Pilihan lainnya adalah bekerja ke kota dan hutan rakyatnya ditinggalkan begitu saja atau dititipkan pada orang lain dengan memberikan biaya pemeliharaan.

Luas kepemilikan lahan juga memberikan pengaruh yang negatif, dimana peningkatan luas lahan sebesar 1 ha akan menurunkan curahan waktu kerja petani terhadap hutan rakyat sebesar 36,209 HOK per tahun. Berdasarkan penelitian terlihat adanya kecenderungan petani yang memiliki lahan hutan rakyat luas hanya menanaminya dengan kayu-kayu tidak dengan pola agroforestry dan tidak dirawat intensif dengan pertimbangan kayu tidak perlu dirawat intensif seperti tanaman pertanian. Petani lebih banyak mencurahkan waktunya pada lahan pertanian (sawah), sedangkan waktu yang tercurah untuk mengelola hutan rakyatnya lebih rendah, karena sebagian besar petani yang memiliki hutan rakyat luas juga memiliki sawah. Seperti hasil penelitian Arwani (2001) petani yang memiliki lahan pertanian/ 
sawah luas akan lebih banyak mencurahkan waktunya dibandingkan dengan petani yang memiliki lahan sawah sempit. Pekerjaan di lahan pertanian khususnya sawah memang membutuhkan curahan waktu yang lebih banyak agar dapat memperoleh hasil panen yang maksimal, ada yang diolah sendiri, diupahkan dan ada yang melibatkan keluarga. Walaupun curahan tenaga kerja yang banyak hanya diperlukan pada musim tertentu seperti musim tanam atau panen. Menurut Ajayi et al. (2009) selain tambahan tenaga kerja, distribusi temporal penggunaan tenaga kerja selama musim pertanian adalah hal yang penting.

Pada umumnya hutan rakyat dikelola oleh orang tua (suami/istri) tanpa melibatkan anakanak. Anak-anak yang sudah dewasa dan tidak bersekolah biasanya bekerja di luar sektor kehutanan atau pertanian. Hal ini juga didukung oleh harapan dari orang tua mereka yang tidak menginginkan anaknya bekerja di sektor kehutanan atau pertanian, karena sektor ini dianggap tidak dapat dijadikan sebagai sumber pendapatan andalan.

Korelasi antara faktor independen curahan waktu kerja dengan faktor lainnya di Desa Sepatnunggal yang paling kuat adalah korelasinya dengan pendapatan hutan rakyat sebesar $0,547 \mathrm{se}-$ dangkan sisanya diterangkan oleh faktor lain yang masing-masing memiliki nilai korelasi di bawah 0,5 yang berarti mempunyai korelasi yang lemah. Masing-masing faktor tersebut mempunyai nilai korelasi sebagai berikut: umur sebesar 0,269 , pengalaman usaha tani sebesar 0,133 , pendidikan sebesar 0,101 dan luas lahan sebesar 0,065 .

Persamaan regresi untuk Desa Sedahayu yakni: $Y=-17,643-3,01 X_{1}+7,32 X_{3}-5,295 X_{4}$ $+21,559 \mathrm{X}_{6}$ menggambarkan bahwa pendugaan perilaku curahan waktu kerja di Desa Sedahayu dijelaskan sebesar 45,5\% oleh empat faktor yakni pendapatan dari hutan rakyat $\left(\mathrm{X}_{1}\right)$, umur $\left(\mathrm{X}_{3}\right)$, pengalaman usaha tani $\left(\mathrm{X}_{4}\right)$, dan luas lahan $\left(\mathrm{X}_{6}\right)$. Seperti di Desa sepatnunggal, di desa ini apabila tidak ada faktor lain maka curahan waktu kerja berpengaruh negatif atau dapat menurunkan sampai 17,643 HOK per tahun. Faktor independent yang mempengaruhi curahan waktu kerja adalah pendapatan dari hutan rakyat, dimana apabila terjadi peningkatan pendapatan hutan rakyat justru akan menurunkan curahan waktu kerja sebesar 3,01 HOK per tahun. Hal ini dimungkinkan ketika petani beranggapan bahwa tanpa dikelola secara intensifpun hutan rakyat dapat memberikan pendapatan yang cukup.

Anggapan tersebut menyebabkan petani memilih menjadi buruh tani atau buruh lainnya di tempat orang lain. Umur petani ternyata berpengaruh positif terhadap curahan waktu kerja petani, dengan bertambahnya usia petani 1 tahun akan meningkatkan curahan tenaganya di hutan rakyat sebesar 7,32 HOK per tahun. Hal ini terkait dengan dengan keengganan pemuda-pemuda tinggal di desa dan mengelola hutan rakyat. Semakin lanjut usia, petani di Desa Sedahayu semakin intensif mencurahkan waktunya pada hutan rakyat termasuk bagi PNS yang baru pensiun. Tetapi pada umumnya kegiatan di hutan rakyat dilakukan produktivitasnya menurun walaupun intensitasnya lebih tinggi, mengingat usianya tersebut.

Pengalaman usaha tani yang semakin lama di desa memungkinkan petani semakin semangat mengelola hutan rakyatnya, namun di desa ini dengan bertambahnya pengalaman usaha tani selama 1 tahun justru menurunkan curahan waktunya di hutan rakyat sebesar 5,295 HOK per tahun. Sedangkan pengaruh luas lahan adalah positif, dimana dengan meningkatnya luas lahan yang dimiliki petani seluas 1 ha akan meningkatkan curahan tenaga petani sebesar 21,559 HOK per tahun. Lahan yang semakin luas tentunya ingin dikelola secara intensif dan akan membutuhkan tenaga kerja yang semakin banyak pula. Dari hasil analisis diketahui bahwa rata-rata luas lahan di Desa Sedahayu adalah 1,52 ha dengan jenis tanaman kayu-kayuan, palawija dan dan tanaman obat-obatan.

Berbeda dengan Desa Bener dan Desa Sepatnunggal, di Desa Sedahayu curahan waktu kerja berkorelasi kuat dengan luas lahan yang dimiliki petani dengan nilai korelasi sebesar 0,602. Faktor umur mempunyai nilai korelasi yang lemah dengan nilai 0,152 , pengalaman usaha tani 0,25 namun berbanding terbalik. Demikian pula dengan pendapatan hutan rakyat nilai korelasinya negatif sebesar 0,438.

Diniyati et al. (2005) menyebutkan bahwa adanya pendapatan dari sektor lain (non hutan rakyat) menunjukkan bahwa petani mempunyai cadangan modal untuk mengelola hutan rakyatnya. Namun dari hasil analisis di ketiga desa tersebut diketahui bahwa pendapatan non hutan rakyat tidak berpengaruh nyata terhadap meningkatnya curahan waktu kerja petani di hutan 
rakyat, bahkan ada kecenderungan semakin besar pendapatan yang diperoleh dari sektor lain (non hutan rakyat) maka petani semakin meninggalkan hutan rakyatnya. Attar (2000) bahwa umumnya para petani yang sudah memperoleh pendapatan dari salah satu sumber dan ternyata sudah mencukupi atau jumlahnya besar maka pendapatan dari sumber lain jumlahnya sedikit. Hal ini terlihat dari pengelolaan yang sangat minim terhadap hutan rakyatnya, karena merasa bahwa kebutuhannya sudah dapat terpenuhi dari sektor lain seperti PNS, wiraswasta, ternak, buruh bangunan dan lain-lain.

\section{KESIMPULAN DAN SARAN}

\section{A. Kesimpulan}

1. Faktor-faktor yang mempengaruhi curahan waktu petani terhadap pengelolaan hutan rakyat wanafarma di ketiga desa studi berbedabeda. Curahan waktu kerja di Desa Bener dipengaruhi oleh besarnya pendapatan dari hutan rakyat dan umur petani, Desa Sepatnunggal dipengaruhi oleh pendapatan dari hutan rakyat, umur, pengalaman tani, pendidikan, dan luas lahan, dan Desa Sedahayu dipengaruhi oleh pendapatan dari hutan rakyat, umur, pengalaman usaha tani, dan luas lahan.

2. Curahan waktu kerja petani di hutan rakyat wanafarma di ketiga desa studi lebih besar dibandingkan di sektor lain/non hutan rakyat (sawah atau jasa), namun curahan waktu kerja petani tersebut masih dibawah curahan kerja normal. Urutan curahan waktu kerja dari yang paling besar berturut-turut adalah Desa Bener $(4,4 \mathrm{HOK}=26,4 \mathrm{jam} / \mathrm{minggu}$, Desa Sepatnunggal (3,9 HOK = 23,4 jam/minggu), dan Desa Sadahayu $(2,7 \mathrm{HOK}=16,2 \mathrm{jam} /$ minggu).

\section{B. Saran}

Untuk meningkatkan curahan waktu kerja petani terhadap pengelolaan hutan rakyat diperlukan upaya pendampingan dari instansi terkait melalui pemberdayaan masyarakat agar masyarakat dapat memanfaatkan waktu yang dimilikinya seoptimal mungkin sehingga produktivitasnya dapat meningkat yang pada gilirannya akan meningkatan pendapatannya.

\section{DAFTAR PUSTAKA}

Ajai, OC., Akinnifesi, F.K., Sileshi, G., \& Kanjipite, W. (2009). Labour inputs and financial profitability of conventional and agroforestry-based soil fertility management practices in Zambia. Agrekon Volume 48 No 3 September 2009: 276292.

Andayani, W. (2005). Ekonomi agroforestri. Yogyakarta: Debut Press.

Arwani, M.M. (2001). Pergeseran pola kerja petani di pedesaan (Penelitian di Desa Ringinharjo, Kecamatan Bantul, DIY. Jurnal Penelitian UNIB Vol.VII, No.2:127-133. Bengkulu.

Attar, M. (2000). Hutan Rakyat; Kontribusi terhadap pendapatan rumah tangga petani dan perannya dalam perekonomian desa (Kasus di Desa Sumberejo, Kabupaten Wonogiri, Jawa Tengah) dalam Hutan Rakyat di Jawa: Perannya dalam Perekonomian Desa. Penyunting Didik Suharjito. Program Penelitian dan Pengembangan Kehutanan Masyarakat (P3KM). Fakultas Kehutanan Institut Pertanian Bogor. Bogor.

Awang, S.A., Andayani, W., Himmah, B., Widayati, W.T., \& Affianto, A. (2002). Hutan Rakyat, Sosial Ekonomi, dan Pemasaran. BPFE. Yogyakarta.

BPS Kabupaten Cilacap. (2006). Kabupaten Cilacap dalam Angka. Cilacap: BPS Kabupaten Cilacap.

Direktorat Jenderal Reboisasi dan Rehabilitasi Lahan Departemen Kehutanan. (1997). SK Dirjen No 88/Kpts/V/1997 tentang Pedoman Penyusunan Rencana Umum Pengembangan Hutan Rakyat Kabupaten. Jakarta

Diniyati, D., Achmad, B., \& Widyaningsih, T.S. (2005). Analisa Partisipasi Petani terhadap Kegiatan Hutan Rakyat. Prosiding Seminar Nasional Pengembangan Pengelolaan dan Pemanfaatan Hasil Hutan Rakyat di Indonesia, tanggal 12 Desember di Yogyakarta: 115-119.

Kalabisova, J., \& Kristkova, Z. (2010). Valuing Socioeconomic Factors of Farmers' Housholds and Economic Effect of Agroforestry System. Agris on-line Papers in Economics and Informatics Volume II Number 4, 2010:11-22.

Karyawan, K.A., Rachmawati, I., \& Sinaga, M. (1996). Persepsi dan partisipasi masyarakat sekitar hutan dalam pembangunan hutan kemasyarakatan di Pulau Rote. Buletin Penelitian Kehutanan Volume 1 No.1:34-42. 
Mile, M.Y. \& Siarudin, M. (2005). Uji coba teknik pengelolaan hutan rakyat model wanafarma dengan pola sengon Jahe. Prosiding Seminar Sehari "Optimalisasi Peran Litbang dalam Mendukung Ragam Pemanfaatan Hutan Rakyat dan Hutan Kemasyarakatan, tanggal 6 Desember di Tasikmalaya :46-61. Bogor.

Sani, La Ode A., Santosa, K.A., \& Ngadiyono, N. (2010). Curahan Tenaga Kerja Keluarga Transmigran dan Lokal pada Pemeliharaan Sapi Potong di Kabupaten Konawe Selatan, Sulawesi Tenggara. Buletin Peternakan Volume. 34 (3): 194-201, Oktober 2010.

Siregar, U.J., Rachmi, A., Massijaya, M.Y., Ishibashi, M., \& Ando, K. (2007). Economic Analysis of Sengon (Paraserianthes falcataria) Commu- nity Forest Plantation, a Fast Growing Species in East Java, Indonesia. Forest Policy and Economics 9: 822-829.

Sobari, M.H., Fachrudin, A., \& Sujana, A. (1996). Pembagian Kerja dan Alokasi Waktu Pencaharian Nafkah pada Rumah Tangga Pengambil Rumput Laut Alam di Kecamatan Cikelet Kabupaten Garut. Akses tanggal 10 Januari 2014, dari http:// respsitory. ipb.ac.id/ bitstream/handle/123456789/26562/Moch. Priatna S. (RK).pdf.

Zakaria, A.K. (2012). Keragaan kesempatan kerja di sektor pertanian dan pengaruhnya terhadap pendapatan rumah tangga pedesaan. Akses tanggal 29 Juni 2012, dari @journal. Unud. ac.id/abstrak/(12) socaq-Zakaria-keragaan kesempatan kerja (1).pdf. 